\title{
COMPARISON OF SELECTED PEDOTRANSFER FUNCTIONS FOR THE DETERMINATION OF SOIL WATER RETENTION CURVES
}

\author{
Michal KUPEC ${ }^{1 *}$, Peter STRADIOT ${ }^{2}$, Štefan REHÁK ${ }^{2}$
}

\begin{abstract}
Soil water retention curves were measured using a sandbox and the pressure plate extractor method on undisturbed soil samples from the Borská Lowland. The basic soil properties (e.g. soil texture, dry bulk density) of the samples were determined. The soil water retention curve was described using the van Genuchten model (Van Genuchten, 1980). The parameters of the model were obtained using the RETC program (Van Genuchten et al., 1991). For the determination of the soil water retention curve parameters, two pedotransfer functions (PTF) were also used that were derived for this area by Skalová (2003) and the Rosetta computer program (Schaap et al., 2001). The performance of the PTFs was characterized using the mean difference and root mean square error.
\end{abstract}

Address

1 Department of Soil Science, Faculty of Natural Sciences, Comenius University in Bratislava, Mlynská dolina B-2, 84215 Bratislava, Slovak Republic

2 Water Research Institute, Nábrežie arm. gen. L. Svobodu 5, 81249 Bratislava, Slovak Republic

* Corresponding author: michal.kupec@fns.uniba.sk

\section{Key words}

- Soil moisture retention curve,

- pedotransfer functions,

- Borská Lowland.

\section{INTRODUCTION}

The retention characteristics and hydraulic conductivity of soil are some of the key parameters in the modelling of a soil water regime (Rehák et al., 2006). Since the determination of the points of a moisture retention curve under laboratory conditions consume a lot of time and money, quite a few works by both domestic authors (Štekauerová et al., 2002, Skalová, 2001, Šútor et al., 2001, Šútor et Štekauerová, 1999) and foreign authors (Arya et Paris, 1981, Cosby et al., 1984, Saxton et al., 1986, Vereecken et al., 1989, Wösten, 1995, 1997, Rawls et al., 1991, Cornelis et al., 2001, Rajkai et al., 2004, Ghanbarian-Alavijeh et al., 2010) deal with the indirect determination of the points of a moisture retention curve with the help of a so-called empirical course, which uses regression analysis (known as pedotransfer functions) (Bouma et Van Lanen, 1987). This methodical course is based on the expected dependence of the water content in soils on such soil characteristics as soil texture, bulk density and organic matter content (Brooks et Corey, 1964, Gupta et Larson, 1979). The results of the pedotransfer functions are then the points or parameters of a moisture retention curve and eventually saturated or unsaturated hydraulic conductivity.

For the determination of the PTF for soils in the Záhorská Lowland (Skalová, 2001), multiple linear regression was used. Using the
PTF, the soil water content with moisture potentials of $h_{w}=-2.5 \mathrm{~cm}$, $-56,-209,-558,-976,-3060$, and $-15300 \mathrm{~cm}$ can be calculated. If granularity categories according to the USDA are used, the linear regression is as follows (Skalová, 2003):

$$
\theta_{h w}=\mathrm{a} \cdot c l a y+\mathrm{b} \cdot s i l t+\mathrm{c} \cdot \text { sand }+\mathrm{d} . \rho_{d}+\mathrm{e}
$$

where $\theta_{h w}$ is the volumetric moisture content $\left[\mathrm{cm}^{3} . \mathrm{cm}^{-3}\right]$ at a certain value of the moisture potential $h_{w}[\mathrm{~cm}]$; clay, silt and sand provide the content [\%] of the particular granularity categories according to the USDA; $\rho_{d}$ is the dry bulk density $\left[\mathrm{g} \cdot \mathrm{cm}^{-3}\right]$; and a, b, c, d and e are the regional parameters determined with the help of a regression analysis.

In order to determine the hydraulic parameters of soil with the help of pedotransfer functions, the Rosetta software (Schaap et al., 2001) was developed. Rosetta is the computer algorithm used for the determination of the water retention parameters of soil according to van Genuchten's model (1980). It uses 5 PTFs, which are distinguished according to the demands of the input data. Databases of soils in moderate up to subtropical climate zones of North America and Europe were used to determine those PTFs, so that the model could be applied in practice as much as possible (Schaap et al., 2001). 
Tab. 1 Basic physical soil parameters.

\begin{tabular}{cccccccc}
\hline & $\begin{array}{c}\text { sand } \\
(\%)\end{array}$ & $\begin{array}{c}\text { silt } \\
(\%)\end{array}$ & $\begin{array}{c}\text { clay } \\
(\%)\end{array}$ & $\begin{array}{c}\rho_{\mathrm{d}} \\
\left(\mathrm{g} / \mathrm{cm}^{3}\right)\end{array}$ & Soil type & Site & $\begin{array}{c}\text { Depth } \\
(\mathrm{cm})\end{array}$ \\
1 & 84.2 & 8.58 & 7.22 & 1.46 & Loamy sand & 1 & 50 \\
2 & 38.04 & 33.92 & 28.04 & 1.44 & Clay loam & 2 & 10 \\
3 & 85.8 & 8.17 & 6.03 & 1.47 & Loamy sand & 3 & 50 \\
4 & 92.6 & 5.31 & 2.09 & 1.36 & Sand & 4 & 10 \\
5 & 90.16 & 5.82 & 4.02 & 1.4 & Sand & 4 & 20 \\
6 & 91.64 & 4.38 & 3.98 & 1.32 & Sand & 4 & 40 \\
7 & 92.88 & 3.55 & 3.57 & 1.36 & Sand & 4 & 30 \\
8 & 92.92 & 4.09 & 2.99 & 1.38 & Sand & 4 & 50 \\
9 & 90.32 & 5.58 & 4.1 & 1.45 & Sand & 5 & 20 \\
10 & 89.52 & 4.7 & 5.78 & 1.44 & Sand & 5 & 30 \\
11 & 89.08 & 5.51 & 5.41 & 1.44 & Sand & 5 & 50 \\
12 & 87.24 & 6.82 & 5.94 & 1.4 & Loamy sand & 5 & 70 \\
13 & 88.12 & 6.18 & 5.7 & 1.4 & Sand & 5 & 80 \\
14 & 91.16 & 4.25 & 4.59 & 1.44 & Sand & 5 & 100 \\
15 & 87.48 & 7.8 & 4.72 & 1.43 & Sand & 6 & 20 \\
16 & 90.92 & 5.55 & 3.53 & 1.46 & Sand & 7 & 30 \\
17 & 90.04 & 6.27 & 3.69 & 1.45 & Sand & 7 & 40 \\
18 & 95.2 & 3.53 & 1.27 & 1.41 & Sand & 7 & 100 \\
19 & 25 & 41.18 & 33.82 & 1.43 & Loamy sand & 2 & 60 \\
20 & 59.88 & 28.76 & 11.36 & 1.38 & Sandy loam & 8 & 50 \\
\hline & & & & & & &
\end{tabular}

Tab. 2 Experimentally determined values of the soil moisture water content $\left(\mathrm{cm}^{3} . \mathrm{cm}^{-3}\right)$ at the values of the moisture potential $\mathrm{pF}=0$; $0.5 ; 1 ; 1.5 ; 2 ; 2.5 ; 3 ; 3.5 ; 3.9 ; 4$ and 18 .

\footnotetext{
$\begin{array}{lllllllllll}\mathrm{pF} & 0 & 0.5 & 1 & 1.5 & 2 & 2.5 & 3 & 3.5 & 3.9 & 4.18\end{array}$

$\begin{array}{lllllllllll}1 & 0.480 & 0.464 & 0.440 & 0.307 & 0.223 & 0.173 & 0.142 & 0.123 & 0.114 & 0.109\end{array}$

$\begin{array}{lllllllllll}2 & 0.498 & 0.464 & 0.457 & 0.445 & 0.418 & 0.387 & 0.379 & 0.339 & 0.310 & 0.303\end{array}$

$\begin{array}{lllllllllll}3 & 0.526 & 0.396 & 0.383 & 0.342 & 0.230 & 0.183 & 0.159 & 0.126 & 0.117 & 0.115\end{array}$

$\begin{array}{lllllllllll}4 & 0.356 & 0.349 & 0.346 & 0.214 & 0.125 & 0.116 & 0.107 & 0.074 & 0.066 & 0.056\end{array}$

$\begin{array}{lllllllllll}5 & 0.499 & 0.389 & 0.372 & 0.289 & 0.111 & 0.091 & 0.071 & 0.059 & 0.055 & 0.050\end{array}$

$\begin{array}{lllllllllll}6 & 0.445 & 0.388 & 0.372 & 0.238 & 0.104 & 0.092 & 0.073 & 0.055 & 0.051 & 0.045\end{array}$

$\begin{array}{lllllllllll}7 & 0.455 & 0.415 & 0.402 & 0.248 & 0.128 & 0.119 & 0.096 & 0.072 & 0.066 & 0.056\end{array}$

$\begin{array}{lllllllllll}8 & 0.477 & 0.354 & 0.335 & 0.248 & 0.109 & 0.098 & 0.079 & 0.061 & 0.057 & 0.051\end{array}$

$\begin{array}{lllllllllll}9 & 0.519 & 0.443 & 0.416 & 0.269 & 0.139 & 0.104 & 0.098 & 0.079 & 0.064 & 0.056\end{array}$

$\begin{array}{lllllllllll}10 & 0.480 & 0.398 & 0.373 & 0.267 & 0.132 & 0.109 & 0.105 & 0.089 & 0.083 & 0.072\end{array}$

$\begin{array}{lllllllllll}11 & 0.478 & 0.393 & 0.377 & 0.239 & 0.113 & 0.080 & 0.073 & 0.055 & 0.048 & 0.044\end{array}$

$\begin{array}{lllllllllll}12 & 0.449 & 0.360 & 0.344 & 0.258 & 0.148 & 0.123 & 0.119 & 0.085 & 0.078 & 0.076\end{array}$

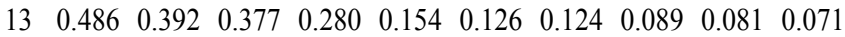

$\begin{array}{lllllllllll}14 & 0.453 & 0.349 & 0.331 & 0.244 & 0.128 & 0.093 & 0.088 & 0.060 & 0.050 & 0.045\end{array}$

$\begin{array}{lllllllllll}15 & 0.422 & 0.310 & 0.274 & 0.239 & 0.145 & 0.094 & 0.063 & 0.053 & 0.048 & 0.046\end{array}$

$\begin{array}{lllllllllll}16 & 0.429 & 0.346 & 0.317 & 0.303 & 0.197 & 0.113 & 0.085 & 0.069 & 0.063 & 0.061\end{array}$

$\begin{array}{lllllllllll}17 & 0.434 & 0.336 & 0.301 & 0.260 & 0.134 & 0.072 & 0.054 & 0.045 & 0.042 & 0.041\end{array}$

$\begin{array}{lllllllllll}18 & 0.416 & 0.316 & 0.288 & 0.220 & 0.072 & 0.044 & 0.034 & 0.028 & 0.027 & 0.026\end{array}$

$\begin{array}{lllllllllll}19 & 0.509 & 0.502 & 0.490 & 0.459 & 0.426 & 0.376 & 0.332 & 0.303 & 0.282 & 0.277\end{array}$

$\begin{array}{lllllllllll}20 & 0.554 & 0.541 & 0.519 & 0.475 & 0.427 & 0.374 & 0.323 & 0.291 & 0.268 & 0.258\end{array}$
}

The use of specific PTFs is determined by the regionally specific properties of soil and the climatic conditions of the areas where given the soils originate. In the case of soils developed under different conditions from the soils on the basis of which the PTFs were created, the reliability of the estimation of the parameters can significantly decline (Wösten et al., 2001).

The objective of this study is to evaluate the applicability of selected PTFs on the soils of the Borská Lowland by comparing the results with the measured values.

\section{MATERIAL AND METHODS}

The analysed soils are located in the territory of the Borská Lowland. Twenty undisturbed soil samples in Kopecký cylinders (100 $\left.\mathrm{cm}^{3}\right)$ were taken from different depths of the soil profile $(0-100$ $\mathrm{cm}$ ). Their granularity (the pipetting method according to Novák) and reduced bulk density (after drying at $105^{\circ} \mathrm{C}$ ) were determined. The samples were divided into groups based on the granularity classes according to the USDA (Soil Survey Manual) as follows: clay $(<0.002$ $\mathrm{mm})$, silt $(0.002-0.05 \mathrm{~mm})$, and sand $(0.05-2 \mathrm{~mm})$ (Tab. 1$)$.

With the help of the negative pressure method with a sand tank and the overpressure method with ceramic disks, the dewatering branch of the moisture retention curve (MRC) was determined. Points of $\mathrm{pF}: 0$; $0.5 ; 1 ; 1.5 ; 2 ; 2.5 ; 3 ; 3.5 ; 3.9 ; 4$ and 18 were measured (Tab. 2).

Based on the measured points of the MRC and with the help of the RETC software (Van Genuchten et al., 1991), the parameters of the van Genuchten model (1980) (1) for the analytic calculation of the MRC were determined:

$$
\theta=\theta_{r}+\frac{\left(\theta_{s}-\theta_{r}\right)}{\left[1+(a h)^{n}\right]^{m}}
$$

where $\theta$ is the actual volumetric soil moisture $\left(\mathrm{cm}^{3} \cdot \mathrm{cm}^{-3}\right) ; \theta_{\mathrm{s}}$ is the saturated moisture $\left(\mathrm{cm}^{3} \cdot \mathrm{cm}^{-3}\right) ; \theta_{\mathrm{r}}$ is the residual moisture $\left(\mathrm{cm}^{3} . \mathrm{cm}^{-3}\right)$; $\alpha$ is the inverse air entry value; $h$ is the moisture potential of the soil $(\mathrm{cm})$; and $\mathrm{n}$ and $\mathrm{m}$ are the empirical shape parameters.

In Table 3 the parameters of the PTF at the defined values of the moisture potential (Skalová, 2003) are presented. The PTF was used for the determination of the soil moisture contents according to the dry bulk density and percentage content of the granularity categories (USDA) of the soils. Based on the PTF results, the parameters of the van Genuchten model (1) were determined using the RETC software.

To estimate the parameters of the moisture retention curve (MRC) according to van Genuchten, the Rosetta model (Schaap et al., 2001) was also used; it uses the included PTFs, which are divided according to the demands of the input data. In this paper the level with the following inputs was used: the percentage content of the granularity

Tab. 3 Regression coefficients of PTFs for the calculation of soil moisture content at given moisture potentials $h_{w}$ (Skalová, 2003).

\begin{tabular}{cccccc}
\hline $\mathrm{h}_{\mathrm{w}}$ [cm] & $\mathrm{a}$ (clay) & $\mathrm{b}$ (silt) & $\mathrm{c}($ sand) & $\mathrm{d}\left(\rho_{d}\right)$ & $\mathrm{e}$ \\
-2.5 & -0.34707 & -0.35014 & -0.35015 & -0.3866 & 35.98715 \\
-56 & -0.48442 & -0.48817 & -0.48962 & -0.26373 & 49.6116 \\
-209 & -0.15504 & -0.16041 & -0.16212 & -0.17461 & 16.638 \\
-558 & 0.1751 & 0.16865 & 0.16737 & -0.21201 & -16.2709 \\
-976 & -0.16688 & -0.17419 & -0.17529 & -0.19197 & 17.94414 \\
-3060 & -0.36232 & -0.37106 & -0.37157 & -0.17934 & 37.52704 \\
-15300 & 0.14062 & 0.13206 & 0.13146 & -0.1442 & -12.8624 \\
\hline
\end{tabular}


categories according to the USDA and the reduced bulk density for the calculation of the model parameters

According to the parameters of the van Genuchten model, which were estimated with the help of the particular PTFs, the course of the retention curves was determined. The tightness of the course of the curves measured and calculated with the help of the PTFs was evaluated according to the values of the mean difference (MD) and the root of the mean squared difference (RMSD), which are commonly used for the evaluation of the accuracy and reliability of PTFs (Wösten et al., 2001).

\section{RESULTS AND DISCUSSION}

The course of the selected moisture retention curves measured and derived by the PTFs is shown in Figs. 1 and 2.
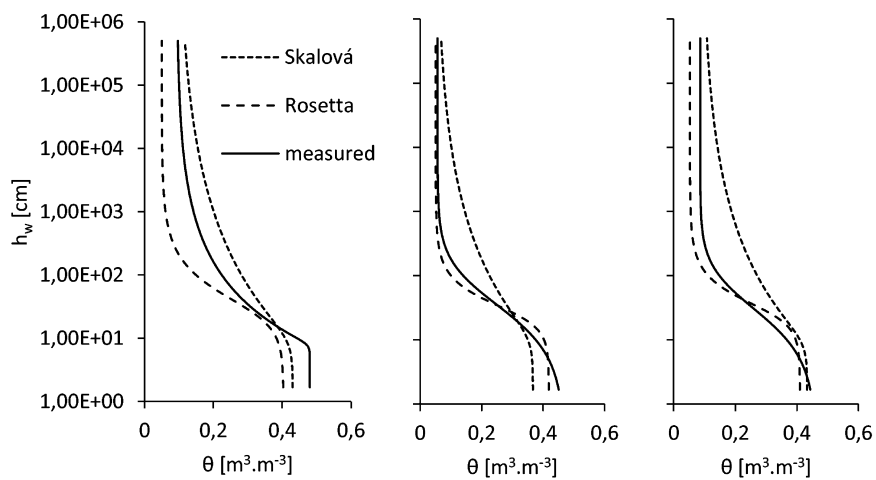

Fig. 1 Course of the measured MRCs, calculated according to the PTF of Skalova and calculated with the help of the Rosetta software for soil samples No. 1, 5 and 10 (from left to right).
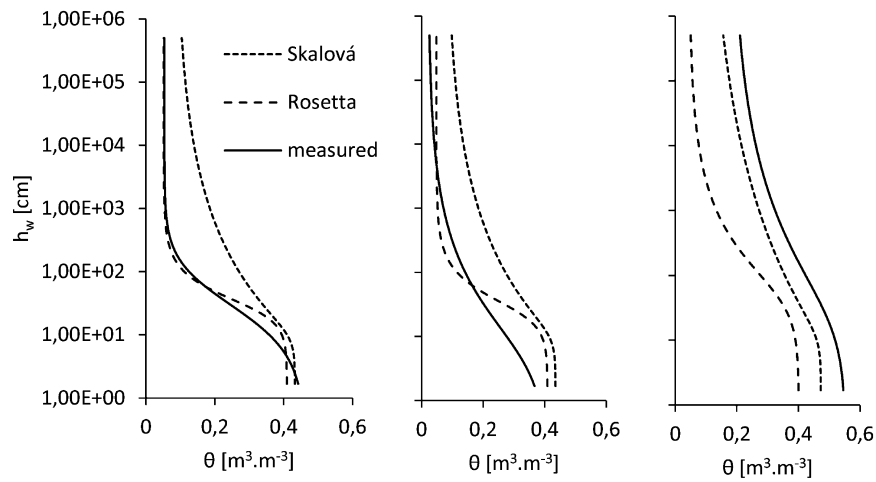

Fig. 2 Course of the measured MRCs, calculated according to the PTF of Skalova and calculated with the help of the Rosetta software for soil samples No. 11, 15 and 20 (from left to right).

The values of the mean differences (MD) and the root of the mean squared differences (RMSD) characterise the difference in the course of the MRC measured and calculated according to the PTF. The coefficient of determination $\left(\mathrm{R}^{2}\right)$ compares the measured and calculated (PTF) values of the moisture at the defined potentials. The results for the set of analysed samples are presented in Table 4 . The values of the mean differences (MD) may be positive or negative depending on whether the values of the moisture calculated with the help of the PTF are higher or lower than the measured values of the moisture. The RMSD values are always positive; the best compliance of the measured MRC and the MRC calculated according to PTF is when the RMSD is zero.

The average values of the mean differences (MD) and the root of the mean squared differences (RMSD) presented in various works
Tab. 4 Values of the coefficient of determination $\left(R^{2}\right)$, the mean difference $(M D)$, and the root of the mean squared differences (RMSD) determined by comparing the points and courses of the $M R C$ measured and calculated with the help of the PTF.

\begin{tabular}{|c|c|c|c|c|c|c|}
\hline & \multicolumn{3}{|c|}{ PTF Skalová } & \multicolumn{3}{|c|}{ Rosetta } \\
\hline & $\mathrm{R}^{2}$ & MD & RMSD & $\mathrm{R}^{2}$ & MD & RMSD \\
\hline 1 & 0.9517 & 0.0044 & 0.0662 & 0.9865 & 0.0021 & 0.0455 \\
\hline 2 & 0.9877 & 0.0220 & 0.1483 & 0.9796 & 0.0016 & 0.0401 \\
\hline 3 & 0.9793 & 0.0050 & 0.0710 & 0.9700 & 0.0009 & 0.0307 \\
\hline 4 & 0.9423 & 0.0023 & 0.0481 & 0.9753 & 0.0034 & 0.0580 \\
\hline 5 & 0.9135 & 0.0004 & 0.0197 & 0.9960 & 0.0037 & 0.0607 \\
\hline 6 & 0.9045 & 0.0008 & 0.0287 & 0.9895 & 0.0045 & 0.0668 \\
\hline 7 & 0.8897 & 0.0007 & 0.0266 & 0.9989 & 0.0030 & 0.0551 \\
\hline 8 & 0.9389 & 0.0025 & 0.0503 & 0.9009 & 0.0052 & 0.0720 \\
\hline 9 & 0.9147 & 0.0014 & 0.0377 & 0.9972 & 0.0046 & 0.0675 \\
\hline 10 & 0.9081 & 0.0010 & 0.0320 & 0.9981 & 0.0054 & 0.0733 \\
\hline 11 & 0.9107 & 0.0004 & 0.0192 & 0.9985 & 0.0089 & 0.0946 \\
\hline 12 & 0.9495 & 0.0015 & 0.0384 & 0.9922 & 0.0073 & 0.0854 \\
\hline 13 & 0.9511 & 0.0014 & 0.0369 & 0.9918 & 0.0054 & 0.0733 \\
\hline 14 & 0.9580 & 0.0013 & 0.0365 & 0.9779 & 0.0077 & 0.0876 \\
\hline 15 & 0.9659 & 0.0023 & 0.0476 & 0.9758 & 0.0115 & 0.1071 \\
\hline 16 & 0.9889 & 0.0019 & 0.0435 & 0.9115 & 0.0034 & 0.0585 \\
\hline 17 & 0.9613 & 0.0012 & 0.0346 & 0.9729 & 0.0083 & 0.0913 \\
\hline 18 & 0.9177 & 0.0021 & 0.0454 & 0.9775 & 0.0110 & 0.1048 \\
\hline 19 & 0.9185 & 0.0137 & 0.1172 & 0.9827 & 0.0120 & 0.1096 \\
\hline 20 & 0.9938 & 0.0270 & 0.1643 & 0.9892 & 0.0034 & 0.0579 \\
\hline rage & 0.9423 & 0.0047 & 0.0556 & 0.9781 & 0.0057 & 0.0720 \\
\hline
\end{tabular}

Tab. 5 Results of the evaluation of PTF by different authors (Tietje et Tapkenhinrichs 1993).

\begin{tabular}{lcc}
\hline & $\mathrm{MD}\left(\mathrm{m}^{3} \cdot \mathrm{m}^{-3}\right)$ & $\mathrm{RMSD}\left(\mathrm{m}^{3} \cdot \mathrm{m}^{-3}\right)$ \\
Gupta and Larson (1979) & 0.0244 & 0.0591 \\
Arya and Paris (1981) & 0.0095 & 0.0611 \\
Rawls and Brakensiek (1985) & -0.0527 & 0.0751 \\
Vereecken et al. (1989) & -0.0145 & 0.0531
\end{tabular}

(Tietje et Tapkenhinrichs 1993, Skalová, 2001, Wösten et al., 2001) are in good compliance with the results presented. Tietje et Tapkenhinrichs (1993) present an overview of the results of the evaluation of PTFs by different authors (Tab. 5).

The high values of the correlation coefficients $\left(\mathrm{R}^{2}\right)$ show the high degree of tightness of the relation between the moistures measured and calculated with the help of the PTF (Tab. 4). The differences between the courses of the MRC measured in the laboratory and calculated with the help of the PTF were also small, and those differences correspond to the results of the authors in Table 5. On average, a little better degree of compliance is obtained by the PTFs created by Skalová. The reason might be the regional relatedness of the evaluated set of soils with the soils used in the creation of the PTFs. 


\section{CONCLUSION}

Pedotransfer functions make the experimental direct determination of the hydraulic characteristics of a soil (which is time and money consuming) simpler. With the help of the proper mathematical model, the hydraulic characteristics of soils can be determined from such basic soil properties as granularity, bulk density, content of humus, etc. The pedotransfer functions that were evaluated in this paper showed a good degree of applicability to the modelling points and courses of the moisture retention curves for the set of soil samples from the region of the Borská Lowland.

\section{REFERENCES}

Arya, L. M. - Paris, J. F. (1981) A physic-empirical model to predict the soil moisture characteristics from particle-size distribution and bulk density data. Soil Sci. Soc. Am. J., 45: 1023-1030.

Bouma, J. - van Lanen, J. A. J. (1987) Transfer function and threshold values: from soil characteristics to land qualities. In: Beek, K. J. (Ed.). Quantified land evaluation. Proceedings of Workshop in ISSS and SSSA, Washington, DC, pp. 106-110.

Brooks R. H. - Corey A.T. (1964) Hydraulic properties of porous media. Hydrology Paper, 3, Colorado State University, 24 pp.

Cornelis, W. M. - Ronsyn, J. - van Meirvenne, M. - Hartmann, R. (2001) Evaluation of pedotransfer function for predicting the soil moisture retention curve. Soil. Sci. Soc. Am. J., 65, 638-648.

Cosby, B. J. - Hornberger, G .M. - Clapp, R. B. - Ginn, T. R. (1984) A statistical exploration of the relationships of soil moisture characteristics to the physical properties of soils. Water Resour. Res., 20, 682-690.

Ghanbarian-Alavijeh, B. - Liaghat, A. - Huang, G.H. - Van Genuchten, M.Th. (2010) Estimation of the van Genuchten soil water retention properties from soil textural data. Pedosphere, 20, 456-465.

Gupta, S. C. - Larson, W. E. (1979) Estimating soil water retention characteristics from particle size distribution, organic matter percent and bulk density. Water Resour. Res., 15: 1633-1635.

Rajkai, K. - Kabos, S. - Van Genuchten, M. Th. (2004) Estimating the water retention curve from soil properties: comparison of linear, nonlinear and concomitant variable methods. Soil Till. Res., 79, 145-152.

Rawls, W. J. - Brakensiek, D. L. (1985) Prediction of soil water properties for hydrologic modelling. In: Jones E., Ward T.J. (eds.): Watershed Management in the Eighties. Proc. Symp. Irrig. Drain. Div. ASCE. Denver, CO. ASCE, New York.

Rawls, W.L. - Gish, T.J. - Brakensiek, D.L. (1991) Estimating soil water retention from soil physical properties and characteristics. Adv. Soil Sci., 16, 213-234.

Rehák, Š. - Janský, L. - Nováková, K. (2006) Fyzika pôdy II (Soil Physics II). Univerzita Komenského, Bratislava, SR, p. 48 (in Slovak).

Saxton, K. E. - Rawls, W. J. - Romberger, J. S. - Papendick, R. I. (1986) Estimating generalized soil-water characteristics from texture. Soil. Sci. Soc. Am. J., 50, 1031-1036.

Schaap, M. G. - Leij, F. J. - Van Genuchten, M. Th. (2001) Rosetta, a computer program for estimating soil hydraulic parameters with hierarchical pedotransfer functions. J. of Hydrology, 251, pp. 163-176.

Skalová, J. (2001) Pedotransferové funkcie pôd Záhorskej nižiny a ich aplikácia pri modelovani vodného režimu pôdy (Pedotrans- fer functions of soils in the Zahorska Lowland and their application in the modelling of a soil water regime). SvF STU Bratislava, p. 112 (in Slovak).

Skalová, J. (2003) Možnosti určenia vlhkostných retenčných kriviek pôd (Possibilities of the determination of moisture retention curves in soil). In: Šiška, B., Igaz, D., Mucha, M., (eds.): Funkcia energetickej a vodnej bilancie $\mathrm{v}$ bioklimatologických systémoch. Zborník príspevkov z Bioklimatologických pracovných dní, Račkova dolina, 2. - 4.9.2003, ISBN 80-8069-244-0 (in Slovak).

Štekauerová, V. - Skalová, J. - Š́́tor, J. (2002) Use of pedotransfer functions for assessment of hydrolimits. Rostlinná výroba, 48, 407-412.

Šútor, J. - Skalová, J. - Štekauerová, V. (2001) Pedotransférové funkcie pre stanovenie bodov vlhkostných retencných kriviek pôd Záhorskej nižiny (Pedotransfer functions for the determination of points of moisture retention curves in the soils of the Zahorska Lowland). Acta Hydrologica Slovaca, 2, 156-160 (in Slovak).

Š́tor, J. - Štekauerová, V. (1999) Pedotransférne funkcie pôd prírodného prostredia Žitného ostrova. J. Hydrol. Hydromech, 47, 443-458.

Tietje, O. - Tapkenhinrichs, M. (1993) Evaluation of pedotransfer functions. Soil Sci. Soc. Am. J., 57: 1088-1095.

Tyler, S. W. - Wheatcraft, S. W. (1989) Application of fractal mathematics to soil water retention estimation. Soil Sci. Soc. Am. J., 53: 987-996.

Van Genuchten, M. Th. (1980) A closed-form equation for predicting the hydraulic conductivity of unsaturated soil. Soil Sci. Soc. Am. J., 44, 892-898.

Van Genuchten, M. Th. - Leij, F. J. - Yates, S. R. (1991) The RETC code for quantifying the hydraulic functions of unsaturated soils. EPA/600/2-91/065. Robert S. Kerr Environmental Laboratory, U.S. Environmental Pretection Agency, Ada, Oklahoma.

Vereecken, H. - Maes, J. - Feyen, J. - Darius, P. (1989) Estimating the soil moisture retention characteristic from texture, bulk density, and carbon content. Soil Sci., 148: 389-403.

Wösten, J. H. M. - Finke, P. A. - Jansen, M. J. W. (1995) Comparison of class and continuous pedotransfer functions to generate soil hydraulic characteristics. Geoderma, 66, 227-237.

Wösten, J. H. M. (1997) Pedotransfer functions to evaluate soil quality. In Gregorich, E.G., Carter, M.R. (Eds.). Soil quality for crop production and ecosystem health. Developments in Soil Science, 25, Elsevier, Amsterdam, 221-245.

Wösten, J. H. M. - Pachepsky, Ya. A. - Rawls, W. J. (2001) Pedotransfer functions: bridging the gap between available basic soil data and missing soil hydraulic characteristics. J. of Hydrology, 251, pp. 123-150. 